\title{
FEDERAL ESTATE TAXATION: "POLIGY FACTS" UNDER SEGTION 2042 (2) HELD TO DETERMINE "INCIDENTS OF OWNERSHIP"
}

The First Circuit in United States v. Rhode Island Hosp. Trust Co. has held that the form of the insurance contract, rather than an assessment of all the facts or the decedent's intent, is determinative of "incidents of ownership" for purposes of section 2042 of the Internal Revenue Code.

W HEN the proceeds of life insurance are payable to the estate of the insured, ${ }^{1}$ the federal estate tax unambiguously directs that such amounts are to be taxed to that estate. ${ }^{2}$ In all other cases, section 2042 (2) of the Internal Revenue Code of 1954 includes proceeds of insurance on a decedent's life in his gross estate only if he possessed "incidents of ownership" in the policy at the time of his death. ${ }^{3}$ The recent case of United States $v$. Rhode Island Hosp. Trust Co.," has broadened the applicability of the "incidents of ownership" test by holding, in effect, that the continuing understanding of the parties as to the actual ownership of the policies is unimportant to a determination of taxability under section 2042 (2).

\footnotetext{
${ }^{1}$ More accurately, INT. REV. CODE of 1954, $\$ 2042$ refers to "policies on the life of the decedent." However, the statutory heading of that section mentions only life insurance: "SEC. 2042. PROCEEDS OF LIFE INSURANCE.

The value of the gross estate shall include the value of all property-

(1) RECETVABLE BY THE EXFCUTOR.-To the extent of the amount receivable by the executor as insurance under policies on the life of the decedent."

In a case such as Commissioner v. Estate of Noel, 380 U.S. 678 (1965), the distinction between "policies on the life of the decedent" and "proceeds of life insurance" can be crucial. In Noel the Supreme Court held that the statutory formula "policies on the life of the decedent" was the broader phrase and included the proceeds of accident in. surance on the theory that the "statute itself... makes no distinction between 'policies on the life of the decedent' which are payable in all events [i.e., life insurance] and those payable only if death comes in a certain way or within a certain time." Id. at 681 .

2 INT. REv. CODE OF 1954, §2042 (1). Except for the question as to whether particular proceeds are from "insurance," see 2 MERTENs, Federal Gift aND Estate TAxation $\S 17.06$, at 334 (1959), $\$ 2042(1)$ has produced few interpretive difficuties. See LowndEs \& Kramer, Federal Estate and Gift TAXes \$13.5, at 278 (2d ed. 1962).

a "The value of the gross estate shall include the value of all property- . . (2) RECEIVABLE BY OTHER BENEFICIARIES.-To the extent of the amount receivable by all other beneficiaries as insurance under policies on the life of the decedent with respect to which the decedent possessed at his death any of the incidents of ownership, exercisable either alone or in conjunction with any other person." INT. REv. CODE OF $1954, \S 2042$ (2).

355 F.2d 7 (1st Cir. 1966).
} 
In 1924 Charles Horton purchased life insurance on the lives of his minor sons, Holton and Trowbridge. Charles designated himself and his wife as beneficiaries, paid all premiums, and retained physical possession of the policies. However, the express terms of each policy recited that the right to change beneficiaries and certain other powers concerning the benefits of the policies were "reserved" to the sons." After his wife's death Charles instructed his sons to execute a change of beneficiary at the insurance company's office, whereby Charles was designated the primary beneficiary and the sons' respective wives were named as successive beneficiaries. Holton Horton died in 1958 , and the proceeds of the policy on his life were included in his gross estate by the Commissioner of Internal Revenue. ${ }^{8}$

Thereupon an action was brought on behalf of the estate for a refund of the tax assessed. The District Court of Rhode Island found that, despite the terms of the policy, the decedent's power with respect to the policy, including his ostensible right to designate a change of beneficiary, had been of a nominal nature only. The court therefore concluded that decedent had possessed none of the incidents of ownership within the meaning of section 2042 (2). ${ }^{7}$ Specifically with regard to decedent's 1952 exercise of the right to alter the policy beneficiary, the court found from the evidence that "beyond any doubt ... he was then acting at the direction and as the instrument of his father who was the real owner of the various incidents of ownership in said policy."8

The First Circuit vacated the judgment of the district court, holding that the decedent's estate was taxable on the insurance proceeds. ${ }^{2}$ To support its conclusion, the court invoked the "principle of heavy predominance of the 'policy facts' over the 'intent facts' . . . "10 Although in theory this rationale leaves room for a

\footnotetext{
${ }^{5}$ The powers reserved to the sons, as detailed by the court of appeals, included the right of assignment; the option to have dividends accumlated, paid in cash, used to purchase paid-up additions, or applied to a reduction in premiums; the opportunity to borrow on the policy; and the necessity for the insured's concurrence in any alteration in the terms of the policy. 355 F.2d at 9.

- Id. at 8-9. The more detailed factual findings of the district court are reported in Rhode Island Hosp. Trust Co. v. United States, 241 F. Supp. 586, 587-89 (D.R.I. 1965).

${ }^{7}$ Rhode Island Hosp. Trust Co. v. United States, 241 F. Supp. 586 (D.R.I. 1965).

${ }^{8}$ Id. at 591 .

- 355 F.2d at 13.

${ }^{10}$ Ibid. "Policy facts" in the view of the court of appeals refers to those rights specifically reserved to particular parties by the written terms of the insurance policy, whereas "intent facts" describes those elements of conduct and understanding contrib-
} 
showing in a particular instance that the "intention" of the parties should be decisive, the court's decision on the facts of the instant case compels the conclusion that it would always decide in accordance with the provisions of the accurately drawn insurance policy. ${ }^{11}$

The "incidents of ownership" test for taxing life insurance proceeds first appeared in the federal tax statute in 1942,12 although it had been promulgated in the Treasury Regulations ${ }^{13}$ and judicially applied $^{14}$ under the 1918 Revenue Act $^{15}$ as early as 1929. The 1942 Revenue Act attempted to clarify earlier interpretive difficulties ${ }^{16}$ by adopting a theory which the Treasury had developed in $1934 . .^{17}$ Thus, two alternative prerequisites to inclusion within the gross estate were prescribed-namely, premium payment by the decedent or possession of "incidents of ownership" at death. ${ }^{18}$ The regulations compiled a non-exclusive list of powers that were deemed to be significant "incidents" and emphasized that such "incidents" were not

uting to a composite "intention" of the parties with respect to ownership of the policy. Id. at 8,12 .

1 See notes $27-30,46.47$ infra and accompanying text.

${ }^{12}$ Int. Rev. Code of $1939, \S 811(\mathrm{~g})$, as amended by ch. $619, \S 404,56$ Stat. 944 (1942) (now INr. REv. CODE OF 1954, § 2042).

12 Treas. Reg. 80, Arts. 25, 27 (1934).

11 Insurance proceeds will be taxed to his estate "so long as [the decedent] ... retains control over those benefits with power to direct their future enjoyment until his death." Chase Nat'I Bank v. United States, 278 U.S. 327, 338 (1929).

${ }^{18}$ Revenue Act of 1918, ch. 18, $\$ 402(f), 40$ Stat. 1098.

${ }_{10}$ The 1918 Revenue Act was the first statutory provision which explicitly taxed life insurance proceeds payable to beneficiaries other than the decedent's estate. The insurance was taxable only if the proceeds exceeded a $\$ 40,000$ exemption for insurance on the decedent's life payable to beneficiaries other than his estate and if the insured had purchased the insurance on his own life. Revenue Act of 1918, ch. 18, $\$ 402(f)$, 403 (a) (4), 408, 40 Stat. 1098 . There was some uncertainty concerning the latter proviso, but the early regulations interpreted it to mean taxation only in proportion to the premiums actually paid by decedent. Treas. Reg. 37, Art. 34 (1919). See Schlesinger, Taxes and Insurance: $A$ Suggested Solution to the Uncertain Cost of Dying, 55 HARv. L. REv. 226, 227-237 (1941). See also Lowndes \& KRAMER, op. cit. supra note 2, § 13.2, at 272. To determine taxability, the regulations in 1929 advocated a combination of the premium payment criterion with an "incidents of ownership" test, the latter being first judicially recognized in the same year. See Chase Nat'I Bank v. United States, 278 U.S. 327,338 (1929).

${ }^{17}$ See note 13 supra and accompanying text.

28 Under the Revenue Act of 1942 the decedent's gross estate was to encompass all property in the following categories: “(2) REGEIVABLE BY OTHER BENEFICIARIES.-To the extent of the amount receivable by all other beneficiaries as insurance under policies upon the life of the decedent (A) purchased with premiums, or other consideration, paid directly or indirectly by the decedent ... or (B) with respect to which the decedent possessed at his death any of the incidents of ownership, exercisable either alone or in conjunction with any other person." Revenue Act of 1942, ch. 619, $\S 404$ (a), 56 Stat. 944. 
limited to technical legal ownership. ${ }^{19}$ Thus the regulations thernselves established substance as a criterion for taxability under section 2042. The 1954 Code eliminated the premium payment standard while statutorily defining "incidents of ownership" only to the extent of specifically including a reversionary interest with a value exceeding five per cent of the policy amount. ${ }^{20}$ Beyond this, Congress has never defined the elusive "incidents," although the legislative history of the $1942 \mathrm{Act}^{21}$ and the regulations ${ }^{22}$ promulgated thereunder would seem to have delineated many of them.

The problem with which Rhode Island deals, however, does not basically concern a determination as to which interests properly constitute "incidents of ownership." Rather, the issue is whether a decedent who ostensibly possessed such incidents actually did retain them. It appears that every court which had previously decided this question had recognized the possibility that powers or rights which by the terms of the insurance contract were possessed by a certain individual might in fact have been exercisable under the given circumstances only by someone else; if such were the case, the purely nominal owner would not be deemed to hold these "incidents of ownership" within the meaning of section 2042 (2). ${ }^{23}$ Furthermore, the burden of proving that the alleged nominal and actual owners intended that possession of all "incidents of ownership" would belong to someone other than the party specifically desiguated by the terms of the policy has been stated to rest upon the litigant making

18 "For purposes of this paragraph, the term 'incidents of ownership' is not limited in its meaning to ownership of the policy in the technical legal sense. Generally speaking, the term has reference to the right of the insured or lis estate to the economic benefits of the policy. Thus, it includes the power to change the beneficiary, to surrender or cancel the policy, to assign the policy, to revoke an assignment, to pledige the policy for a loan, or to obtain from the insurer a loan against the surrender value of the policy, etc." Treas. Reg. \$20.2042-1 (c) (2) (1958). Accord, Treas. Reg. 105, §81.27 (1942).

10 INT: REv. CODE OF 1954, \$2042 (2).

21 H.R. REP. No. 2333, 77th Cong., 2d Sess. 57, 163 (1942); S. REP. No. 1631, 77th Cong., 2d Sess. 234-36 (1942); 88 CoNc. Rec. 6379 (1942) (remarks of Representative Disney).

${ }^{22}$ Treas. Reg. 105, $\$ 81.27$ (1942); Treas. Reg. $\$ 20.2042-1$ (c) (2) (1958). See note 19 supra.

28 Estate of Piggott v. Commissioner, 340 F.2d 829, 834-35 (6th Cir. 1965); Prunier v. Commissioner, 248 F.2d 818, 820-21 (1st Cir. 1957); District of Columbia v. Wilson, 216 F.2d 630, 681 (D.C. Cir. 1954); United States v. Burgo, 175 F.2d 196, 197 (3d Cir. 1949); Hall v. Wheeler, 174 F. Supp. 418, 421 (S.D. Me. 1959); Fried v. Granger, 105 F. Supp. 564, 566 (W.D. Pa. 1952), aff'd per curiam, 202 F.2d 150 (3d Cir. 1953); Edward D. Lacey, 41 T.C. 329, 336 (1963); Estate of Michael Collino, 25 T.C. 1026, 1033-34 (1956); Estate of Edward Doerken, 46 B.T.A. 809, 813 (1942). 
that assertion. ${ }^{24}$ Because this burden necessitates proof of intent, it has been stated to be a heavy one. ${ }^{25}$ Indeed, the cases substantiate this conclusion, for the assertion that the decedent was not the actual owner has frequently been unsuccessful. ${ }^{26}$

The Rhode Island decision appears to depart from this body of precedent. While arguably recognizing the possible relevance of "intent facts" as opposed to "policy facts," 27 the court of appeals disposed of many of the leading cases by stating that they have "almost uniformly held the 'policy facts' (reservation of rights in the policy) impregnable to attack from the "intent facts." "28 This seems to be an excessively strong characterization of the prior decisions. While the cases have imposed upon the taxpayer the burden of refuting the policy facts, ${ }^{29}$ and most have held that the taxpayer had failed to do so, ${ }^{30}$ nevertheless, none of them has in effect precluded the possibility that the intent facts could prevail.

The Rhode Island court also relied upon the recent decision of the Supreme Court in Commissioner v: Estate of Noel. ${ }^{31}$ In that case, the husband had purchased two airline flight accident insurance policies with his wife's money, stated that they belonged to the wife, made her the beneficiary, and left the policies in her possession..$^{32}$ Since the contract granted the decedent certain rights which were legally exercisable ${ }^{33}$ and only a temporary physical inability attribu-

${ }^{26}$ In the instant case the district court held that the estate had sustained the burden of establishing that the father rather than the decedent possessed the incidents of ownership of the policy. $241 \mathrm{~F}$. Supp. at 590 .

${ }^{28}$ In suits challenging the imposition of the estate tax under $\$ 2042(2)$, there is a heavy burden on the estate to prove non-ownership of the "incidents" and to sustain the position that no tax avoidance scheme existed. See, e.g., Estate of Piggot v. Commissioner, 340 F.2d 829, 835 (6th Cir. 1965); Estate of Michael Collino, 25 T.C. 1026, 1032-33 (1956).

${ }^{20}$ Only three of the cases cited in note 23 supra held for the taxpayer on grounds that the estate had sustained the requisite burden as to non-ownership-namely, Prunier v. Commissioner, 248 F.2d 818 (Ist Cir. 1957); United States v. Burgo, 175 F.2d 196 (3d Cir. 1949); Estate of Edward Doerken, 46 B.T.A. 809 (1942).

27355 F.2d at 18 . See note 10 supra.

${ }^{28} 355$ F.2d at 12 . (Emphasis added.) Given the undisputed evidentiary facts as to the terms of the policy and the "intention" of the parties, the court of appeals made its determination with respect to the proper weight to be accorded these elements as a matter of law. Id. at 10 .

${ }^{20}$ Notes 23-26 supra and accompanying text.

${ }^{96}$ Notes 25-26 supra and accompanying text.

3130 U.S. 678 (1965).

s. Id at $679-80$.

ss The policy stated that the insured possessed the right to designate a change in beneficiary and to assign the policies. Id. at 680 . 
table to decedent's presence on the aircraft could have prevented their actual exercise, ${ }^{34}$ the insurance proceeds were taxed to his estate. The Court, refusing to accept the estate's argument that the decedent's wife had bought the policies or alternatively that he had assigned them to her, held that the very statements on the policies negatived any contention as to the wife's ownership. ${ }^{35}$ The Court did not state that the policy statements were irrebuttable, but implied only that the estate had failed to produce sufficient evidence to counterbalance the express terms of the policy. ${ }^{30}$ It does not seem, therefore, that Noel forecloses the possibility of a successful showing that actual possession of the incidents of ownership in a policy is held by someone other than the person who would be indicated by a mere consideration of the policy provisions.

In those cases which have recognized the possibility of intent facts outbalancing policy facts ${ }^{37}$ it does not appear to have been required that one who is purportedly the actual owner of a policy must be in a position such that he could gain redress in the courts if the nominal owner were to assert his technical rights in the policies. Rather, the courts have contented themselves with speaking simply of "actual ownership" without articulating any other standard than that its existence in a given circumstance is a question of fact. ${ }^{38}$ In Rhode Island, however, it could reasonably have been found, in accordance with the conclusions of the district court, ${ }^{39}$ that the parties had always acted with the understanding that the father was the actual owner of the policy. In addition it is possible that any independent

${ }^{34}$ As a practical matter, the Court acknowledged that the decedent could not have exercised his right to change beneficiaries or to assign the policies in the few hours between the time of their issuance and the moment of his death because the time interval was short and further because he was airborne and the policies were in the possession of his wife at home. Id. at 683-84. Nevertheless, the Court held that the ultimate test was the "general, legal power to exercise ownership, without regard to the owner's ability to exercise it at a particular moment." Id. at 684.

ss "The contracts themselves granted to Mr. Noel the right either to assign the policies or to change the beneficiary without her consent. Therefore the contracts she bought by their very terms rebut her claim that she became the complete, unconditional owner of the policies with an irrevocable right to remain the beneficiary." Id. at 683.

so "The contention that Mrs. Noel bought the policies and therefore owned them rests solely on her testimony that she furnished the money for their purchase, intend. ing thereby to preserve her right to continue as beneficiary." Ibid. (Emphasis added.)

"rr Cases cited note 23 supra.

se See ibid.

8241 F. Supp. at 591. 
exercise by Holton of the powers which were technically his could have rendered him legally liable to his father, who might have proceeded in a local court on two theories. In the first instance, he might have contended that any actions performed by Holton with respect to the policy were undertaken merely as the father's agent. This view could be evidenced by the fact that the insurer's local representative informed the father rather than the son that a change of beneficiary was desirable.40 Indeed, the son acceded to his father's request even though he understood the change would be inconsistent with his own needs. ${ }^{41}$ Thus both contracting parties apparently assumed the agency relationship. - Secondly, it could be argued that a constructive trust in favor of the father had been created, since any attempted exercise of power by the son would have defeated the father's original purpose and resulted in an unjust enrichment of the son. ${ }^{42}$ Although there may be some uncertainty as to whether the father could have gained redress under Rhode Island law, it is nevertheless clear that such theories are acceptable in numerous states. ${ }^{43}$ Moreover, the First Circuit seems to have recognized that there did exist a legal right in the father to forestall

${ }^{10} I d$. at 589.

42 Id. at 588. Prior to 1952, the year in which he executed the change of beneficiary at his father's request, Holton knew that his ill health prevented him from acquiring sufficient insurance to take care of his own family. Holton had only limited life insurance and had attempted to purchase more without success.

"See Cronan v. Metropolitan Life Ins. Co., 50 R.I. 323, 147 Atl. 618 (1929), in which a mother paid all the premiums for a policy on her son's life. The policy gave the son power to change beneficiaries, and he substituted his wife for his mother, who had been the original beneficiary. Subsequent to the substitution, but before the mother had notice of it, she endorsed a note in exchange for his promise to pledge the policy to her as security. He did not do so. After the son's death the mother successfully sued to recover from the insurance company the amount of the premiums she had paid. Some language in the opinion would support the mother's right to recover merely because she had paid premiums. Id. at 325, $147 \mathrm{Atl}$. at 619 . See also Modern Woodmen of America v. Brennan, 111 F. Supp. 735 (D.R.I. 1953), interpreting the Cronan result as predicated on an agreement between the insured and the payor of the premiums. However, it would not seem difficult in Rhode Island to imply such an agreement from the course of action pursued by the parties even if there were no evidence of an explicit understanding.

${ }^{8} \mathrm{An}$ insured has been held without power to make a legally binding change of beneficiary, notwithstanding the purported grant of such power to him by the policy, where equitable principles give the original beneficiary a right to the proceeds superior to that of the new beneficiary. Wellhouse v. United Paper Co., 29 F.2d 886 (5th Cir. 1929) (right to change beneficiaries held in trust for the originial beneficiary); Reilly v. Henry, 187 Ark. 420, 60 S.W.2d 1023 (1933); Beed v. Beed, 207 Iowa 954, 222 N.W. 442 (1928); Jacobson v. New York Life Ins. Co., 199 Iowa 770, 202 N.W. 578 (1925); Katzman v. Aetna Life Ins. Co., 309 N.Y. 197, 128 N.E.2d 307 (1955) (change of beneficiary constituted fraud upon premium-paying beneficiary). 
exercise by the son of those powers ostensibly granted to him by the policy:44 It held, nevertheless, that the possibility that the father could have proceeded at law or in equity against Holton was "no answer" to the fact that the terms of the insurance contract recited that various incidents of ownership were reserved to Holton, and that Holton could have exercised them.45

In light of the court's rejection of the uncontroverted intentions and actions of the parties to the effect that all incidents of ownership in the policies actually resided in the father, it is difficult to imagine any factual situation in which the accurately drawn terms of the policy ${ }^{46}$ would not be given controlling effect. ${ }^{47}$ This complete reliance upon the form of the transaction, and the concomitant disdain for the admittedly more elusive substance, flies in the teeth of the approach taken in so many particular areas of the tax law that the rationale of the instant decision may virtually be said to contravene a general principle. ${ }^{48}$ Many of the estate tax provisions, for

\footnotetext{
" 355 F.2d at 11. The only situation in which the court expressed doubt as to the father's ability to have action taken by Holton set aside concerned an assignment of the policy by Holton to a creditor. Here the court stated that the assignment "could not be said . . . in all such cases to be nugatory." Ibid. Note here, however, that it was the father who had weakened his own equities by clothing Holton with the indicia of ownership.

${ }^{45}$ Ibid. The court's analysis thus proceeds on the basis of a somewhat tenuous "right-power" distinction. In other words, while Horton may not in fact have had the legal right vis-à-vis his father to take various independent actions with respect to the policy, nevertheless because he ostensibly possessed the naked power to proceed in a certain manner, the son would be deemed to retain some of the "incidents of ownership" at his death.

"The Rhode Island court specifically excepted from its "policy facts" rule any case in which it was shown that the policy terms were not written according to the instructions of the contracting party. Id. at 13. See National Metropolitan Bank v. United States, 115 Ct. Cl. 396, 87 F. Supp. 773 (1950) (provision inserted by in. surance agent on his own initiative held irrelevant to a $\$ 2042$ determination).

${ }^{67}$ Perhaps the strongest case for an argument that the intentions of the parties differed from the rights conferred by the policy would be in a situation in which the parties formally in writing contracted that one of them should be the actual owner of all rights in the policy. In view of the fact that the court did not consider it relevant that the father might have had an actionable claim against Holton, it does not appear that an action by the father based upon a breach of the most solemnly formalized contract would have produced a different result. In fact, the court indicates that one purpose of its decision is to vitiate the effectiveness of any such agreement, however formal, for $\$ 2042$ (2) purposes. 355 F.2d at 13.

${ }^{6}$ The fact that the court of appeals in Rhode Island appears to have departed from a large body of precedent does not necessarily mean that its position-rigid ad. herence to form-is unsupportable by various policy considerations. For example, in the area of estate planning, family arrangements can become rather complicated, especially if private oral agreements are involved. Therefore, decisions which embrace only the form of the transaction adopt a rule that alleviates an evidentiary burden and tends to create judicial certainty. Furthermore, it could not be argued tbat the parties'
} 
example, are specifically directed toward preventing the form of certain pre-death transfers from obscuring their underlying testamentary nature. ${ }^{49}$ Similarly, section 482 of the 1954 Code $^{50}$ grants the Treasury sweeping discretion to re-allocate income among certain related business entities. Complicated rules of attribution are codified to permit recognition of the substance of corporation ownership. ${ }^{51}$ Cases known by name to every tax lawyer state that it is the substance of a transaction which is controlling. ${ }^{52}$ In the final analysis, the law should cut both ways: if the taxpayer may not hide behind form to escape taxation, the Government's attempt to tax the possession of a purely formal status should not be permitted. ${ }^{\mathbf{3}}$

intentions would necessarily be restricted by the failure of the court to consider the substance of the transaction. In the instant case, for example, the father could easily have adjusted the form of the transaction to his actual intention by requiring Holton to assign the insurance policy to him.

${ }^{10}$ See INT. REv. CODE of $1954, \S \S 2035-38$. These sections make includable in a decedent's gross estate property which he had transferred during his lifetime for less than an adequate money's worth consideration, and which, technically, as a matter of property law, he did not own at his death. In each of the cases taxed by these sections, however, the substance of the taxpayer's action is distinctly testamentary in nature. Additionally, see INT. REv. CoDE of 1954, $\$ 2041$, which basically makes a general power of appointment includable in the gross estate. Such a power, in form, is not property; but in substance it gives the possessor a right to dispose of property testamentarily, a power which is indistinguishable from the right which actual ownership would confer.

BO INT. REV. CODE OF I954, $\$ 482$.

-1 INT. Rev. CODE of 1954, \$318.

62 The landmark case manifesting a concern for substance, as opposed to mere form, is Gregory v. Helvering, 293 U.S. 465 (1935). The form-substance dichotomy has been applied in various areas of tax law by numerous cases. See, e.g., Higgins v. Smith, 308 U.S. 473 (1940); Wolf v. Commissioner, 357 F.2d 483 (9th Cir. 1966); Estate of McNichol v. Commissioner, 265 F.2d 667 (3d Cir.'1959); Georgia-Pacific Corp. v. United States, 264 F.2d I6I (5th Gir. 1959); Kocin v. United States, 187 F.2d 707 (2d Cir. 1951); Commissioner v. National Carbide Corp., I67 F.2d 304 (2d Cir. 1948), aff'd 336 U.S. 422 (1949); Chisholm v. Commissioner, 79 F.2d 14 (2d Cir. 1935).

A recent case, Estate of Chrysler v. Commissioner, 361 F.2d 508 (2d Cir. 1966), dealt with an analogous problem of form versus substance under INT. REv. CoDE OF 1954, $\$ 2040$. The court, however, preferring to view the substance of the transactions, declared that the decedent was merely the nominal owner who had employed a joint tenancy device to make completed gifts to his children without using the cumbersome procedure of guardianship and formal trusts formerly required under New York law. 361 F.2d at 510. Chrysler thus supports the view taken by prior $\$ 2042$ cases (see note 23 supra) that a court should render its decision in accordance with the demonstrated substance of a transaction.

${ }^{83}$ It is interesting to note the approach which the Internal Revenue Service no doubt would have taken if in the Rhode Island situation the father had predeceased his son. It seems apparent that the father's proven control and beneficial interest in the policy would have been labeled an interest in property and taxed under INT. REv. CODE of 1954, $\$ 2033$. Such a holding would appear to be more in line with the notion that taxability is determined by the substance of the transaction. See note 52 supra. Nevertheless, the Rhode Island case illustrates the agility of the Service in seeking to tax either formal or substantive interests as the case may arise. 